\title{
Piece on Human Condition Written for the Office of the Americas
}

\author{
University Synagogue, November 2, 2002
}

Rabbi Beerman was frequently called upon to offer invocations at the annual meetings of nonprofit organizations in the Los Angeles area; he did so on a regular basis for Death Penalty Focus and Human Rights Watch. This invocation for the LA-based Office of the Americas sought to peer into the human soul. It taught that human beings are, at once, solitary individuals alone in their creativity and desperately in search of belonging to something larger than themselves. Rather than privilege one over the other, Beerman conveyed with concise eloquence that human beings continually navigate between these distinct states.

Who of us has not been thinking of this troubled time in which we have been fated to live? Where shall wisdom be found? You remember those words of Shakespeare: "What a piece of work is man. How noble in reason; how infinite in faculties; in form and moving, how express and admirable; in action how like an angel; in apprehension how like a god." Hamlet was of course mad, and looking at our world today, it is very clear, only a madman could say such a thing. When we think of what human beings have done to one another, how can we hold to a brighter vision of the human possibility?

There is no vision of human life worth having that does not include the two poles of human need and desire. All of us need a sense of our own, individual, private integrity; our own personality, something not meant to be breached, or assaulted, or violated by others. That is the basis of whatever dignity we possess. The right to be ourselves in solitude-that is what fires creation and discovery. And that is what is always under assault. For we are born into a world that precedes us, 
a world already made by other people and we must, if we are to become ourselves, turn that world into our own.

But we also need the other pole of human need and desire. We need to lose our sense of self, to be part of something larger than ourselves, sometimes in moments of great passion. And that is what is the basis of religion, and sex, and politics, and society. That is what it means to experience that exquisite sense of what one human being owes to another, can mean to another.

The right to be ourselves, a sense of an inviolable integrity, and the need to be part of something larger than ourselves. Is that not what we want for every human being? How shall we achieve this when these two poles of human need and desire are almost daily being threatened and mutilated? How shall we do that when we live on a precarious planet "where a small affluent elite perches fearfully on top of three continents of hungry peons" (to borrow Harvey Cox's penetrating words).

Something there is in us, a burning realization, which tells us that there is beauty, but there are the humiliated. And with the writer Albert Camus, we say: "Whatever difficulties the enterprise may present, I would like never to be unfaithful either to the one or the other." There is beauty and there, the humiliated. There is love, and there are the victims of injustice, and surely everyone associated with the OA would say, I would like never to be unfaithful to the one or the other, whatever difficulties the enterprise may represent.

We pray for all those who work for a world of reason and compassion, may courage be given to those who work to abate life's miseries and heal its wounds, who are comrades in the only battle worth waging, the battle to create a more humane world.

\section{COMMENTARY BY STEPHEN ROHDE}

With the memories of 9/11 a year earlier- "this troubled time" —on his mind, Leonard addressed the annual gathering of the Office of the Americas, founded in 1983 to pursue international justice and peace and oppose "the long-standing international culture of militarism," on whose Advisory Board he had served for decades.

Here, as throughout his life, Leonard confronted "what human beings have done to one another," expressing his commitment to the twin goals of upholding "individual, private integrity" while being "part of something larger than ourselves."

Leonard knew and taught the Jewish tradition of placing life above all else. It was his compassionate opposition to the death penalty, which brutally denies the dignity of each human being, which had first brought us together in the struggle to abolish capital punishment. Here he bemoans how the "inviolable integrity" of the individual is "almost daily being threatened and mutilated."

In Leonard's words, one can hear the third-century Mishnah text: "Therefore, humans were created singly, to teach you that whoever destroys a single soul, 
Scripture accounts it as if he had destroyed a full world; and whoever saves one soul, Scripture accounts it as if she had saved a full world."

In the end, Leonard urges his audience, "whatever difficulties the enterprise may represent," to build "a world of reason and compassion," offering courage to "those who work to abate life's miseries and heal its wounds" in "the battle to create a more humane world.” Leonard was describing his entire life's work. 